\title{
Liderlik Tiplerinin Öğretmenlerdeki Örgütsel Sessizlik Üzerindeki Yordayıcılığının İncelenmesi ${ }^{*}$
}

\author{
Gülsün KARABAY ${ }^{1}$, Elif Özge ERBAY ${ }^{2}$
}

\begin{abstract}
Öz: Bu araştırmanın amacı liderlik tiplerinin öğretmenlerdeki örgütsel sessizlik üzerindeki etkisini incelemektir. Araştırma ilişkisel tarama desenindedir. Araştırmanın evrenini İstanbul ilindeki liseler ve ortaokullarda çalışan öğretmenler oluşturmaktadır. Örneklem ise Yeni Koronavirüs Hastalığı (COVID-19) salgını sebebiyle kolayda örnekleme yöntemiyle seçilmiş, toplamda 401 öğretmene ulaşılmıştır. Verilerin toplanmasında Okul Müdürleri Liderlik Stili Ölçeği ve Öğretmenler İçin Örgütsel Sessizlik ölçekleri kullanılmıştır. Araştırmanın sonucunda okul yöneticilerinin liderlik tiplerinin, öğretmenlerde örgütsel sessizlik davranışını anlamlı şekilde yordadığı görülmüştür. Bu çalışma ile okul yöneticilerinin örgütsel sessizlik konusundaki farkındalıklarını artırarak okul içinde katılım odaklı etkileşimi teşvik eden yönetim modellerini içeren eğitim programları önerilmektedir.
\end{abstract}

Anahtar Sözcükler: Öğretmenler, Eğitim, Liderlik Tipleri, Örgütsel Sessizlik

\section{Examining The Prediction of Leadership Types on Organizational Silence Among Teachers}

\begin{abstract}
The study aims to reveal the effect of leadership types on organizational silence among teachers. In this study, a correlational research design was used. The population of the study is teachers working in public high schools and secondary schools in Istanbul. The sample was determined through the convenient sampling method because of the Novel Coronavirus Disease (COVID-19) outbreak, and 401 teachers were reached. School Principals Leadership Style Scale and Organizational Silence Scales for Teachers were used to collect data. According to the results, the leadership types of the school managers significantly predicted organizational silence behavior of the teachers. Through this study, training programs for school administrators were recommended to increase the awareness of organizational silence and to encourage the participation based interactive management models.
\end{abstract}

Keywords: Teachers, Education, Leadership Types, Organizational Silence

* Bu araştırma 'Öğretmenlerde Liderlik Tiplerinin Psikolojik Sermaye ve Örgütsel Sessizlik Üzerindeki Etkisinin İncelenmesi' isimli yüksek lisans tezinden türetilmiştir.

1 İstanbul Aydın Üniversitesi, Lisansüstü Eğitim Enstitüsü, Psikoloji Bölümü, İstanbul, Türkiye, e-posta: gulsunkarabay@stu.aydin.edu.tr, ORCID: https://orcid.org/0000-0003-3651-0742

2 İstanbul Aydın Üniversitesi, Fen-Edebiyat Fakültesi, Psikoloji Bölümü, İstanbul, Türkiye e-posta: eliferbay@aydin.edu.tr , ORCID: https://orcid.org/0000-0001-7927-0596
} 
Bugün en bilinen arama motorlarından olan Google, liderlik ile ilgili beş yüz milyona yakın web sitesi listelemektedir. Öte yandan Google akademik, başlığında liderlik kelimesi bir kez geçen iki yüz binden fazla makale listelemektedir (Mcshane ve Von Glinow, 2016). En iyi yönetim tarzı kimine göre sert tutumlu bir yönetimken, kimine göre de nazik ve sevecen olan yönetim şeklidir. Kimi, bireyler özgür olsun derken kimi de kamusal düzenden yana tavır koymaktadır (Rousseau, 2017). Dolayısıyla farklı yönetim tarzları olduğu için bu yönetim tarzlarına liderlik yapanların da farklı liderlik tiplerine sahip olduğu söylenebilir. Liderlik tiplerinin de örgüt çalışanlarında farklı etkiler oluşturacağı tahmin edilmektedir. Benzer durumun okullarda da geçerli olduğunu gösteren ve farklı liderlik tiplerinde okul yöneticilerini odağına alan çok sayıda araştırmaya rastlamak mümkündür. Bu liderlik tiplerinin pek çok farklı değişkenle ilişkisinin ele alındığı görülmüştür. Son dönemde ise örgütsel sessizlik kavramıyla da ele alındığı görülmeye başlanmıştır.

Türkiye'de çok bilinen bir atasözü der ki: "Söz gümüşse sükût altındır". Konuşmanın kişilerin başına iş açacağı, sessiz kalmanınsa kişiyi koruyacağına yönelik bu inanışın, Türk kültüründeki karşılığını, otoritenin fazlaca görünür olduğu ve çalışanla işveren arasındaki güç mesafesinin yüksek olduğu kültürlerde tespit etmek mümkündür (Hofstede, 1991). Bu düşüncenin örgütlerdeki karşılığı, örgütsel sessizlik kavramı olarak 2000 yılında Morrison ve Milliken'in yaptığı çalışmada alanyazına girmiştir. Özdemir ve Uğur'a (2013) göre atasözlerinde uyum göstermeye yönelik mesajlar verilirken, bugün bu sessizlik, bir geri çekiliş ve tepki olarak görülmektedir. Oysa Alparslan ve Kayalar’a (2012) göre, bu çağdaki örgütlerin daha iyi olabilmeleri ve gelişebilmeleri için çalışanlarının düşüncelerini özgürce ve cesurca ifade etmeleri beklenmektedir.

Örgütsel sessizlik Synder'in 1974'te ortaya attığı kendini uyarlama teorisine dayandırılabilmektedir. Buna göre, birey topluma uyum sağlayarak sosyalleşmeye çalışmaktadır. Bu çaba onun toplum içindeki davranışlarını da belirlemektedir (Synder, 1974, akt. Uçar, 2016). Kendini uyarlama becerisi yüksek kişilerin örgüt ya da ortama uyum sağlayarak bir davranış geliştirdikleri bu becerinin düşük olduğu kişilerin ise bundan farklı davranışlar sergilediği görülmektedir (Uçar, 2016). Kendini uyarlama teorisine göre örgütsel sessizlik veya örgüt içinde ses çıkarma durumu yine örgütün içindeki baskın görüşten kaynaklanmakta ve örgütten destek alıp almıyor olmakla ilişkilendirilmektedir (Premeaux ve Bedeian, 2003). Örgütsel sessizlik, ayrıca çalışanların işlerini ve kurumlarını iyileştirmeye yarayacak olan bilgi ve görüşlerini bilerek saklamaları olarak da tanımlanmıştır (Morrison ve Milliken, 2000). Başka bir deyişle, çalışanların örgütü daha iyi hale getirmek için işi veya işyeriyle ilgili teorik ve/veya davranışsal unsurlarla ilgili fikir ve düşüncelerini bilinçli olarak esirgemesi ve sessizleşmesidir (Çakıc1, 2007). Örgütsel sessizlik kabullenici, korunmacı ve korumacı olarak üç çeşittir (Aktaş ve Şimşek, 2014; Taşkıran, 2010). Kabullenici sessizlik çalışanların örgütteki gelişmeleri sorgusuz olarak kabullenmeleri sonucunda sessiz kalmalarıdır (Taşkıran, 2010). Korunmacı sessizlik, zor durumda kalmamak için (Çakıcı, 2010) çalışanın bilgi ve görüşlerini ifade etmemesidir (Gül ve Özcan, 2011). Korumacı sessizlik ise bireylere, örgüte ve topluma yarar sağlama niyetiyle fedakârlık yaparak işle alakalı bilinen şeyleri çalışanın gizlemesine denir. Burada amaç, örgüt menfaatini korumaktır (Gül ve Özcan, 2011). Diğer bir ifadeyle korumacı sessizlik korunmacı sessizlikten bireyin kendisinden ziyade başkalarını düşünerek sessiz kalması şeklinde ayrışmaktadır (Taşkıran, 2010).

Örgütsel sessizlik bağlamında örgüt yönetimi üzerine gerçekleştirilen çalışmalar, özellikle son 10 yılda bazı araştırmacılarca eğitim alanında da yapılmaya başlanmıştır (Demirtaş, Özdemir ve Küçük, 2016; Kahveci ve Demirtaş, 2013; Nartgün ve Kartal, 2013; Yaman ve Ruçlar, 2014). Okullar da sosyal örgütler olarak değerlendirildiğinde okul yöneticilerinin, birer lider olarak örgüt ortamını düzenlemesi ve birlikte çalıştığı öğretmenlerle olan ilişkisi, öğretmenlerin örgüt içi davranışlarını öngörmek adına önem kazanmaktadır.

Alanyazında liderliğe dair yaklaşımlar davranışsal yaklaşım, özellikler yaklaşımı, durumsal yaklaşım ve yeni yaklaşımlar biçiminde sınıflandırılmaktadır (Bakan, 2008; Tengilimoğlu, 2005). Bu yaklaşımların hiçbirisi tek başına liderlik kavramını tüm yönleriyle açıklayamasa da birbirlerinin tamamlayıcısı olarak gösterilebilir (Bakan, 2008). Bu tanımlar çerçevesinde, kapsamı oldukça geniş olan liderlik kavramına dair, bu araştırmaya konu edilen üç farklı liderlik tipinden söz edilecektir: Dönüşümcü, sürdürümcü ve serbest 
bırakıcı liderlik.

Dönüşümcü liderler, takipçileriyle aktif etkileşim kurarak onlardaki enerjiyi bulup harekete geçirmektedir (Burns, 1978). Bu şekilde dönüşümcü lider; takipçilerin ihtiyaçlarını, değer yargılarını etkileyebilen liderdir (Koçel, 2018; Riggio, 2018). Takipçiler ve lider, karşılıklı olarak birbirlerinden etkilenmektedir. Bu etkilenme durumu değişim gösterebilmektedir. Lider bu değişimler esnasında bir köprü vazifesi görmekte ve dengeyi sağlamaktadır. Lider bu vazifeyi iyi yapabilirse örgüte bağlılığı arttırmayı sağlar (Doğan, 2016). Alanyazında transaksiyonel, eylemsel, işlemci ve etkileşimci liderlik olarak da anılan sürdürümcü liderlik; kurallar ve yönergeler, dikey iletişim, somut hedefler, pozisyon kaynaklı güç gibi ögelerden oluşmaktadır. Bu tip lider için işlerin bitirilmesi, çalışanların itaati ve onların işlerini yerine getirmeleri için katı bir ödül-ceza sistemi bulunmaktadır (Erdoğan, 2014). Diğer yandan, dönüşümcü ve sürdürümcü gibi aktif liderlik yaklaşımlarının tam zıttı olarak anılan serbest bırakıcı liderlik yaklaşımının (Rowold ve Schlotz, 2009); liderlerin örgüt içi işleyişte pasif kalan, astlarını kendi haline bırakan (Karip, 1998) ve çalışanlarına istenmediği müddetçe bilgilendirme ve yönlendirmede bulunmayan (Terzi ve Kurt, 2005) özellikler taşıdığı aktarılmaktadır.

İlgili alanyazında liderlik ile ilgili sayısız çalışma bulunmaktadır. Bu bağlamda araştırmalara bakıldığında, liderlik tipleri ve örgütsel sessizlik üzerine alanyazında yapılan çalışmalarda, Erol ve Köroğlu (2013) liderlik tarzlarının örgütsel sessizlik ile ilişkisini, Kahveci ve Demirtaş (2013) okul yöneticisi ve öğretmenlerin örgütsel sessizlik algılarını, Daççı Sönmez ve Cemaloğlu (2018) liderlik tiplerinin öğretmenlerin örgütsel sessizliği ve maruz kaldıkları yıldırma-mobbing- davranışlarını, Kavrayıcı (2019) okul müdürlerinin liderlik tiplerinin demografik değişkenler bağlamındaki değişimi, Turunç ve Alkan (2020) liderlik türlerinin örgütsel sessizliğe etkisinde kariyer memnuniyeti rolünü çalışmışlardır. Bu çalışmada ise liderlik tiplerinin öğretmenlerde örgütsel sessizliği yordayıp yordamadığı araştırılmıştır.

Araştırmanın okul yöneticilerine örgütsel sessizlik ile ilgili farkındalık kazandıracağı umulmaktadır. Araştırmaya konu olan liderlik tiplerinin okullardaki sessizliği ne kadar açıkladığı bilgisinin de okul yöneticileri için önemli katkılar sağlayacağı düşünülmektedir. Diğer deyişle, çalışanların örgüt içinde sessiz kalma davranışlarının, bağlı bulundukları yöneticilerin benimsedikleri liderlik tiplerinin etkisiyle ortaya çıkabileceği düşünülmektedir.

Bu bağlamda, araştırma kapsamında aşağıda yer alan hipotezler test edilecektir:

$\mathrm{H}_{1}$ : Okul yöneticilerinin liderlik tipleri ile öğretmelerin örgütsel sessizlik davranışları arasında anlamlı bir ilişki vardır.

H1a: Dönüşümcü liderlik ile örgütsel sessizlik arasında anlamlı bir ilişki bulunmaktadır.

$\mathrm{H}_{1 \mathrm{~b}}$ : Serbest bırakıcı liderlik ile örgütsel sessizlik arasında anlamlı bir ilişki bulunmaktadır.

Hı: Sürdürümcü liderlik ile örgütsel sessizlik arasında anlamlı bir ilişki bulunmaktadır.

$\mathrm{H}_{2}$ : Okul yöneticilerinin liderlik tipleri, öğretmelerin örgütsel sessizlik davranışları üzerinde anlamlı bir etkiye sahiptir.

$\mathrm{H}_{2 a}$ : Dönüşümcü liderlik örgütsel sessizlik üzerinde anlamlı bir yordayıcılığa sahiptir.

$\mathrm{H}_{2 b}$ : Serbest bırakıcı liderlik örgütsel sessizlik üzerinde anlamlı bir yordayıcılı̆̆a sahiptir.

$\mathrm{H}_{2 c:}$ Sürdürümcü liderlik örgütsel sessizlik üzerinde anlamlı bir yordayıcllğa sahiptir.

\section{Yöntem}

Araştırma nicel yaklaşımlardan ilişkisel tarama deseniyle yürütülmüş̧ür. Araştırmanın evreni İstanbul'da resmi ortaokul ve liselerde çalışan öğretmenlerdir. Örneklem ise COVID-19 sebebiyle kolayda örnekleme yöntemi olarak belirlenmiş ve araştırmaya toplam 401 katılımcı dahil olmuştur.

\section{Veri Toplama Araçları}

Veri toplamak için örgütsel sessizliğin ölçümünde Kahveci ve Demirtaş (2013) tarafından geliştirilen Öğretmenler İçin Örgütsel Sessizlik Ölçeği (ÖIÖSÖ) ve liderlik tiplerinin değerlendirilmesinde ise Akan, 
Yıldırım ve Yalçın (2014) tarafından geliştirilen Okul Müdürleri Liderlik Stilleri Ölçeği (OMLSÖ) kullanılmıştır. Bu araştırma kapsamında kullanılan iki ölçeğin iç tutarlılığa bağlı güvenirliklerini incelemek amacıyla Cronbach alfa değerleri hesaplanmıştır. Ölçekler için hesaplanan iç tutarlılık katsayıları Tablo 1'de gösterilmiştir.

Tablo 1

Ölçeklere Ait Cronbach Alfa Güvenirlik Katsayılan

\begin{tabular}{llrr}
\hline Ölçek & Boyut & Madde sayıs1 & Cronbach alfa \\
\hline \multirow{4}{*}{ Örgütsel sessizlik } & İzolasyon & 3 & 0.83 \\
\cline { 2 - 4 } & Yönetici & 3 & 0.82 \\
\cline { 2 - 4 } & Sessizliğin kaynă̆1 & 5 & 0.78 \\
\cline { 2 - 4 } & Duygu & 3 & 0.76 \\
\cline { 2 - 4 } & Okul ortamı & 4 & 0.75 \\
\cline { 2 - 4 } & Ölçeğin geneli & 18 & 0.91 \\
\hline \multirow{3}{*}{ Liderlik stili } & Dönüşümcü & 20 & 0.96 \\
\cline { 2 - 4 } & Serbest birakıc1 & 8 & 0.89 \\
\cline { 2 - 4 } & Sürdürümcü & 7 & 0.77 \\
\hline
\end{tabular}

Buna göre, örgütsel sessizlik ölçeğinin izolasyon, yönetici, sessizliğin kaynağı, duygu ve okul ortamı boyutları için hesaplanan alfa katsayıları sırasıyla $0.83 ; 0.82 ; 0.78 ; 0.76$ ve 0.75 ve ölçek genelinde ise $\alpha=0.91$ olarak bulunmuştur. Diğer yandan, liderlik sitili ölçeğinin dönüşümcü, serbest bırakıcı ve sürdürümcü liderlik boyutları için hesaplanan alfa katsayılarının sırasıyla $0.96 ; 0.89$ ve 0.77 olarak hesaplanmıştır. Her iki ölçek için de elde edilen katsayılar, ölçeklerin iç tutarlılığa bağlı güvenirliğinin yeterli düzeyde olduğunu işaret etmektedir (bkz. Tablo 1).

\section{Verilerin Toplanması ve Analizi}

Veriler araştırmacı tarafından 2020-2021 eğitim-öğretim yılının hemen başında, öğretmenlerin yüz yüze seminere çağrıldığı 5 gün içerisinde okullara gidilerek yüz yüze toplanmıştır. Araştırma kapsamında, öncelikle liderlik tipleri ile örgütsel sessizlik arasındaki ilişkiyi tespit etmek için Pearson korelasyon analizi yapılmışır. Liderlik tiplerinin öğretmenlerin sessizlik davranışları üzerindeki yordayıcılığını test etmek amacıyla ise doğrusal regresyon analizi gerçekleştirilmiştir.

\section{Bulgular}

Araştırma kapsamında yer alan değişkenler arasındaki ilişkilerin test edilmesi için yapılan korelasyon analizi sonucunda (bkz. Tablo 2), dönüşümcü liderlik ile örgütsel sessizlik arasında negatif yönlü anlamlı bir ilişki tespit edilmiştir $(r=-0.374 ; p<0.01)$. Ayrıca, dönüşümcü liderliğin örgütsel sessizliğin alt boyutlarıyla olan ilişkileri incelendiğinde, izolasyon $(r=-0.262 ; p<0.01)$, yönetici $(r=-0.252 ; p<0.01)$ ve sessizliğin kaynağ1 $(r=-0.275 ; p<0.01)$ boyutlarıyla düşük, duygu $(r=-0.301 ; p<0.01)$ ve okul ortamı $(r=-0.499 ; p<0.01)$ boyutlarıyla ise orta düzeyde anlamlı ilişkiler tespit edilmiştir.

Serbest bırakıcı liderlik ile örgütsel sessizlik arasında ise düşük düzeyli ve pozitif yönlü anlamı bir ilişki tespit edilmiştir $(r=0.236 ; p<0.01)$. Serbest bırakıcı liderliğin örgütsel sessizliğin alt boyutlarıyla olan ilişkileri incelendiğinde, izolasyon $(r=0.155 ; p<0.01)$, sessizliğin kaynağ $(r=0.229 ; p<0.01)$ ve duygu $(r=0.161 ; p<0.01)$ boyutlarıyla düşük düzeyde, okul ortamıla ise orta düzeyde $(r=0.491 ; p<0.01)$ anlamlı ilişkiler tespit edilmiştir.

Diğer yandan, örgütsel sessizliğin sürdürümcü liderlik ile arasında da düşük düzeyde ve pozitif yönlü anlamlı bir ilişki bulunmuştur $(r=0.238 ; p<0.01)$. Sürdürümcü liderliğin sessizliğin alt boyutlarıyla ilişkileri incelendiğinde ise izolasyon $(r=0.178 ; p<0.01)$, sessizliğin kaynağ $(r=0.218 ; p<0.01)$ ve duygu $(r=0.176$; $p<0.01)$ boyutlarıyla düşük, okul ortamı boyutuyla ise orta düzeyde $(r=0.416 ; p<0.01)$ anlamlı ilişkiler tespit edilmiştir. Buna göre $\mathrm{H} 1$ hipotezi ve alt hipotezlerinin desteklendiği görülmektedir. 
Tablo 2

Liderlik Tipleri ile Örgütsel Sessizlik Puanlarn Arasındaki İlişkilere Ait Pearson Korelasyon Katsayıları

\begin{tabular}{|c|c|c|c|c|c|c|c|c|c|c|}
\hline & Değişkenler & 1. & 2. & 3. & 4. & 5. & 6. & 7. & 8. & 9. \\
\hline 1. & Dönüşümcü liderlik & 1 & & & & & & & & \\
\hline 2. & Serbest bırakıcı liderlik & $-.436^{* *}$ & 1 & & & & & & & \\
\hline 3. & Sürdürümcü liderlik & $-.261^{* *}$ & $.749^{* *}$ & 1 & & & & & & \\
\hline 4. & İzolasyon & $-.262^{* *}$ & $.155^{* *}$ & $.178^{* *}$ & 1 & & & & & \\
\hline 5. & Yönetici & $-.252^{* *}$ & .070 & .063 & $.592^{* *}$ & 1 & & & & \\
\hline 6. & Sessizliğin kaynağı & $-.275^{* *}$ & $.229^{* *}$ & $.218^{* *}$ & $.676^{* *}$ & $.692^{* *}$ & 1 & & & \\
\hline 7. & Duygu & $-.301^{* *}$ & $.161^{* *}$ & $.176^{* *}$ & $.597^{* *}$ & $.434^{* *}$ & $.578^{* *}$ & 1 & & \\
\hline 8. & Okul ortamı & $-.499^{* *}$ & $.491^{* *}$ & $.416^{* *}$ & $.482^{* *}$ & $.364^{* *}$ & $.526^{* *}$ & $.502^{* *}$ & 1 & \\
\hline \multirow[t]{3}{*}{9.} & Örgütsel sessizlik toplam puan & $-.374^{* *}$ & $.236^{* *}$ & $.238^{* *}$ & $.832^{* *}$ & $.789^{* *}$ & $.890^{* *}$ & $.766^{* *}$ & $.654^{* *}$ & 1 \\
\hline & $\bar{X}$ & 3.54 & 2.52 & 3.01 & 3.43 & 3.59 & 3.18 & 3.56 & 2.73 & 3.37 \\
\hline & ss & 0.78 & 0.85 & 0.64 & 1.02 & 1.03 & 0.85 & 0.90 & 0.78 & 0.74 \\
\hline
\end{tabular}

Liderlik tiplerinin örgütsel sessizlik üzerindeki yordayıcılıklarını test etmek için yapılan regresyon analizleri neticesinde (bkz. Tablo 3); dönüşümcü, serbest bırakıcı ve sürdürümcü liderliğin birlikte, örgütsel sessizlikteki değişimin \%16'sını açıladığı görülmektedir $(R=0.404 ; F=25.74 ; p<0.001)$. Standardize beta katsayılarına ait anlamlılık değerleri incelendiğinde, liderlik stillerinden sadece dönüşümcü $(\beta=-0.35$; $p<0.01)$ ve sürdürümcü $(\beta=0.19 ; p<0.05)$ liderliğin örgütsel sessizliğin anlamlı yordayıcısı olduğu anlaşılmıştır. Buna göre örgütsel sessizlik üzerinde dönüşümcü liderliğin negatif, sürdürümcü liderliğin ise pozitif bir yordayıcı olduğu anlaşılmaktadır. Elde edilen sonuçlara göre $\mathrm{H}_{2 b}$ hipotezi destek görmemiş, $\mathrm{H}_{2 a}$ ve $\mathrm{H}_{2 c}$ hipotezleri destek görmüş, dolayısıyla araştırmanın 2. hipotezi kısmen kabul edilmiştir.

Tablo 3

Liderlik Tiplerinin Örgütsel Sessizlik Üzerindeki Yordayıcıllğını Test Etmek İçin Gerçekleştirilen Regresyon Analizi Sonuçları

\begin{tabular}{llllll}
\hline Değişken & $\mathrm{B}$ & Standart Hata & $\beta$ & $\mathrm{t}$ & $\mathrm{p}$ \\
\hline (Sabit) & 4.01 & 0.27 & & 15.04 & 0.00 \\
Dönüşümcü liderlik & -0.33 & 0.05 & -0.35 & -6.83 & 0.00 \\
Serbest birakıc liderlik & -0.05 & 0.07 & -0.06 & -0.81 & 0.42 \\
Sürdürümcü liderlik & 0.22 & 0.08 & 0.19 & 2.76 & 0.01 \\
\hline $\mathrm{R}=0.404$ & $\mathrm{R}^{2}=0.163$ & & $\mathrm{~F}=25.74$ & & $p<0.001$ \\
\hline
\end{tabular}

\section{Sonuç ve Tartışma}

Araştırmada liderlik tipleri ile örgütsel sessizlik arasında anlamlı bir ilişki bulunmuştur. Erol ve Köroğlu da (2013) bu sonucu desteklemektedir. Buna göre okul müdürlerinin dönüşümcü liderlik özelliklerine sahip olmasıyla öğretmenlerde örgütsel sessizliğin azaldığı, okul müdürlerinin serbest bırakıcı ya da sürdürümcü liderlik özelliklerini taşımasıyla öğretmenlerde örgütsel sessizliğin arttığı görülmektedir. Nartgün ve Kartal'a (2013) göre okullarda örgütsel sessizliğin nedenleri arasında yöneticilerin otoriter tutumları, düşük performansları ve izolasyon korkusu vardır. Sunulan bu nedenler sürdürümcü ve serbest bırakıcı liderlerin özellikleri sonucudur ve bu bağlamda araştırmanın bulgusunu desteklemektedir.

Kendini uyarlama teorisine göre bireyler sosyalleşme amacıyla topluma uyum sağlamak istediklerinden örgütteki egemen görüşe uymaya yatkındırlar (Uçar, 2016). Sürdürümcü liderlik tarzında dikey iletişim, kurallar ve makamın verdiği gücü kullanmak gibi unsurlar önemlidir. Katı bir ödül-ceza sistemi de olduğu düşünüldüğünde (Erdoğan, 2014) okul yöneticisinin görüşünün egemen olacağı ifade edilebilir. Dolayısıyla ona karşı olan grubun veya öğretmenin, yöneticisinin otoriter tutumdan kaynaklı olarak sessiz kalacağ1 söylenebilir. Buna ek olarak, sosyalleşme bağlamında okul yöneticileri tarafından da izole edilmemek amacıyla öğretmenlerin sessiz kalmış olabileceği düşünülmektedir. Sürdürümcü liderlik örgütsel sessizliğin diğer boyutlarına göre en çok okul ortamı boyutu ile orta düzeyde $(r=0.416 ; p<0.01)$ anlamlı ilişki göstermektedir. Bu durum okul yöneticilerinin oynadığ1 rolün örgütsel sessizlikte olan önemini ortaya koymaktadır. Benzer şekilde serbest bırakıcı liderliğin de örgütsel sessizliğin diğer boyutlarına göre en çok okul ortamı boyutuyla orta düzeyde $(r=0.491 ; p<0.01)$ anlamlı ilişki göstermesi de bunu desteklemektedir. Serbest bırakıcı liderliğin çalışanlarda düşük performansa yol açtığı belirtilmektedir (Taş, Çelik ve Tomul, 2007). Çünkü liderlerin varlığı ya da yokluğu arasında belirgin bir farklılık yoktur (Karip, 1998). Aslında otorite tamamen ortadan kaldırılmıştır (Aykan, 2004). Dolayısıyla otoritenin olmadığı bu liderlik tarzında 
okul içindeki bazı öğretmenler baskın olabilir ve otorite rolüne bürünebilir. Kendini uyarlama teorisine göre bu durum, grubun dışında kalmak istemeyecek diğer öğretmenlerin de baskın olanlar tarafından dışlanmama isteği ile yine örgütsel sessizliğe neden olabilecektir.

Yapılan bazı çalışmalarda (Daççı Sönmez ve Cemaloğlu, 2018; Taşkıran, 2010) dönüşümcü liderlik özellikleri taşıyan liderlerin çalışanların örgütsel sessizliklerinin azalmasını sağladığını belirtmiştir. Bu durum kendini uyarlama teorisi bağlamında ele alındığında, dönüşümcü lider olan okul yöneticisinin öğretmenle etkileşime girmesinin önemi vurgulanabilir. Dönüşümcü liderlik özellikleri gösteren okul yöneticilerinin okulda oluşturdukları demokratik ortam sonucu öğretmenler daha çok ses çıkarmaya yönelik davranışlarda bulunurlar. Diğer öğretmenlerin de bu duruma kendilerini uyarladıkları söylenebilir. Dolayısıyla okul yöneticilerinin dönüşümcü liderlik özelliği arttıkça, kendini uyarlama teorisine göre öğretmenlerde örgütsel sessizlik davranışının azalması beklenen bir durumdur. Dönüşümcü liderlik tipi örgütsel sessizliğin alt boyutlarından okul ortamıyla diğer alt boyutlara göre daha yüksek $(r=-0.499 ; p<0.01)$ orta düzeyde anlamlı ilişki göstermiştir. Bu da yukarıda belirtildiği üzere okul yöneticilerinin rolünün önemini ortaya koymaktadır.

Çalışanların kurumlarına duydukları güveni, iyi oluşlarını ve temel motivasyonlarını düşüren örgütsel sessizlik, kişinin zamanla işini yapmak için gerekli becerilerinin de gelişimini sekteye uğratarak performansının düşüşüne sebep olabilmektedir (Milliken, Morrison ve Hewlin, 2003). Bu noktada çalışanın sessizlik davranışının önlenmesi, kurum yöneticilerinin söylenmeyen ya da söylenemeyene dair bilgi edinerek örgütün ve çalışanın gelişimine dair müdahil olabileceği fırsatları görebilmek adına önem taşımaktadır.

Bu bağlamda okul yöneticilerinin, örgütsel sessizlikle ilgili farkındalıklarının artırılacağı seminerler ve hizmet içi eğitimlerle; işbirlikçi ve öğretmen katılımın teşvik edildiği bir okul ortamı yaratabilen yönetim biçimlerinin oluşturulabileceği, doğru liderlik tarzlarıyla öğretmeni destekleyen ve sessiz kalmak yerine eğitim ve öğretime dair yenilikçi fikirlerin ifade edilebildiği bir örgüt iklimi oluşturmanın mümkün olabileceği düşünülmektedir. Eğitim-öğretim örgütlerinin amaçları düşünüldüğünde, örgütsel sessizliğin azaltılmasına yönelik bu çalışmaların önemi yadsınmamalı ve üst yöneticiler tarafından da gereken önem ve destek sağlanabilmelidir. Öte yandan, farkındalık ve gelişim odaklı bu ve benzeri eğitimlerden öğretmenlerin de faydalanmaları, sessizlik davranışının olası zararları hakkında aydınlatıcı olacaktır. Örgütsel sessizliğin okul ortamındaki yansımalarına dair yapılan araştırmalar, verilen hizmet içi eğitimlerle broşür, görsel, infografik vb. materyaller yoluyla okul yöneticilerine ulaştırılabilir; konuyla ilgili dikkat çekici örneklerin yer aldığı bir içerikle zenginleştirilebilir ve tekrar eden seminerler yoluyla okul yöneticilerinin liderlik uygulamalarına dair bilgilerinin güncel tutulması sağlanabilir.

\section{Sinurlılıklar}

Araştırma örnekleminin seçiminde katılımcıların, görev yapılan okul çeşitliliği, bölge ve okul türüne göre kategorize edilerek, alan çeşitliliğini de göz önünde bulundurarak branş öğretmenlerini kapsayacak şekilde ortaokul ve lise kademesi öğretmenlerini içermesi hedeflenmekteydi. Ancak sistematik örnekleme tekniğiyle ulaşılmak istenen asgari öğretmen katılımcıya, COVID-19 sebebiyle alınan önlemler kapsamında ülke genelinde okulların kapatılması sebebiyle ulaşılamamıştır. 2020 yılı yaz ayları itibariyle, normalleşme süreci adımları içerisinde seminer dönemi için göreve çağrılan öğretmenlerden, yalnızca araştırmacının ulaşabildiği 401 öğretmen, kolayda örnekleme yöntemiyle katılımcı olarak araştırmaya dahil edilebilmiştir. Kolayda örnekleme yöntemiyle elde edilen verilerin araştırma evrenini temsil gücünün düşük olması, bu çalışmanın başlıca sınırlılıkları arasında yer almaktadır.

Çalışmanın yapıldığı zaman dilimi, kurum yöneticilerinin (salgın tedbirleri vb. sebebiyle) ciddi ve riskli kararlar almasını gerektiren bir kriz dönemine denk geldiğinden, katılımcı öğretmenlerin yöneticilerinin liderlik tiplerine dair algılarında normal koşullarda olduğundan daha hassas yanıtlar verebilmiş olduğu 
düşünülmektedir.

Tüm bu sebeplerden ötürü, gelecek çalışmalarda öncelikle temsil gücü daha yüksek bir örneklem grubuyla araştırmanın tekrarı önerilmekte, ayrıca öğretmenlerin örgün eğitime normal koşullarda devam edebildiği bir dönemde de veri toplanarak, sonuçların farklılığının/değişiminin gözlemlenmesinin önemli olabileceği düşünülmektedir.

\section{Yazar(lar)ın Beyanı}

Araştırmacıların katkı oranı beyanı: Araştırma yüksek lisans tezinden üretilmiştir. Araştırmacı Gülsün KARABAY olup Dr. Öğr. Üyesi Elif Özge ERBAY tez danışmanıdır.

Etik Kurul Kararı: Bu çalışma, İstanbul Aydın Üniversitesi Etik Komisyonu'nun 28.01.2020 tarihli ve 2020/01 sayılı kararıyla uygun bulunmuştur.

Çatışma beyanı: Herhangi bir çatışma beyanı bulunmamaktadır.

Destek ve teşekkür: Araştırmacılar herhangi bir kurum ya da kuruluştan destek almamışlardır.

\section{Kaynaklar}

Akan, D., Yıldırım, İ. ve Yalçın, S. (2014). Okul Müdürleri Liderlik Stili Ölçeğinin geliştirilmesi (OMLSÖ). Elektronik Sosyal Bilimler Dergisi, 13(51), 392-415.

Aktaş, H. ve Şimşek, E. (2014). Örgütsel sessizlik ile algılanan bireysel performans, örgüt kültürü ve demografik değişkenler arasındaki etkileşim. Akdeniz I.I.̇.B.F. Dergisi, 14(28), 24-52.

Alparslan, A. ve Kayalar, M. (2012). Örgütsel sessizlik: Sessizlik davranışları ve örgütsel ve bireysel etkileri. Mehmet Akif Ersoy Üniversitesi Sosyal Bilimler Enstitüsü Dergisi, 4(6), 136-147.

Aykan E. (2004). Kayseri'de faaliyet gösteren girişimcilerin liderlik özellikleri. Erciyes Üniversitesi Sosyal Bilimler Enstitüsü Dergisi, 17(2), 213-224.

Bakan, İ. (2008). Örgüt kültürü ve liderlik türlerine ilişkin algılamalar ile yöneticilerin demografik özellikleri arasındaki ilişki: Bir alan araştırması. KMU İ̈BF Dergisi, 8(14), 13-40.

Burns, J. M. (1978). Leadership. New York: Harper \& Row.

Çakıc1, A. (2007). Sessizliğin teorik temelleri ve dinamikleri. Ç.Ü. Sosyal Bilimler Enstitüsü Dergisi, 16(1), 145162.

Çakıcı, A. (2010). Örgütlerde iş gören sessizliği, neden sessiz kalmayı tercih ediyoruz?. Ankara: Detay Yayıncılık.

Daççı Sönmez, E. ve Cemaloğlu, N. (2018). İlköğretim kurumu yöneticilerinin liderlik tarzları ile öğretmenlerin yaşadıkları yıldırma (mobbing) ve örgütsel sessizlik davranışları arasındaki ilişki. Kastamonu Ĕ̆itim Dergisi, 26(6), 1951-1960. doi: 10.24106/kefdergi.2253

Demirtaş, Z., Özdemir, T. Y. ve Küçük, Ö. (2016). Okulların bürokratik yapısı, örgütsel sessizlik ve örgütsel sinizm arasındaki ilişki. Kuram ve Uygulamada Eğitim Yönetimi, 22(2), 193-216. doi:10.14527/kuey.2016.008

Doğan, S. (2016). Ĕ̆itim yönetiminde liderlik: Çă̆daş liderlik yaklaşımları. N. Koşar (Ed.), (s. 98-142) içinde. Ankara: Pegem Akademi.

Erdoğan, İ. (2014). Eğitim ve okul yönetimi. İstanbul: Alfa Yayınları.

Erol, G. ve Köroğlu, A. (2013). Liderlik tarzları ve örgütsel sessizlik ilişkisi: Otel işletmelerinde bir araştırma. Seyahat ve Otel İşletmeciliği Dergisi, 10(3), 45-64.

Gül, H. ve Özcan, N. (2011). Mobbing ve örgütsel sessizlik arasındaki ilişkiler: Karaman il özel idaresinde görgül bir çalışma. İ̈BF Dergisi, 1(2), 107-134.

Hofstede, G. (1991). Cultures and organizations: Software of the mind. London: McGraw-Hill. 
Kahveci, G. ve Demirtaş, Z. (2013). Okul yöneticisi ve öğretmenlerin örgütsel sessizlik algıları. Eğitim ve Bilim, 38(167), 50-64.

Karip, E. (1998). Dönüşümcü liderlik. Kuram ve Uygulamada Eğitim Yönetimi Dergisi, 4(4), 443-465.

Kavrayıcı, C. (2019). Okul müdürlerinin liderlik stillerinin çeşitli değişkenler açısından incelenmesi. Anadolu Üniversitesi Eğitim Fakültesi Dergisi, 3(2), 116-131.

Koçel, T. (2018). İşletme yöneticiliği. İstanbul: Beta.

Mcshane, S. ve Von Glinow, M. (2016). Örgütsel davranış (A. Günsel ve S. Bozkurt, Çev.). Ankara: Nobel.

Milliken, F. J., Morrison, E. W. ve Hewlin, P. E. (2003). An exploratory study of employee silence: Issues that employees don't communicate upward and why. Journal of Management Studies, 40(6), 1453-1476.

Morrison, E. ve Milliken, F. (2000). Organizational silence: A barrier to change and development in a pluralistic world. The Academy of Management Review, 25(4), 706-725.

Nartgün, Ş. ve Kartal, V. (2013). Öğretmenlerin örgütsel sinizm ve örgütsel sessizlik hakkındaki görüşleri. Bartın Üniversitesi Ĕ̆itim Fakültesi Dergisi, 2(2), 47-67.

Özdemir, L. ve Uğur, S.S. (2013). Çalışanların "örgütsel ses ve sessizlik" algılamalarının demografik nitelikler açısından değerlendirilmesi: Kamu ve özel sektörde bir araştırma. Atatürk Üniversitesi İktisadi ve İdari Bilimler Dergisi, 27(1), 257-281.

Premeaux, S. F. ve Bedeian, A. G. (2003). Breaking the silence: The moderating effects of self-monitoring in predicting speaking up in the workplace. Journal of Management Studies, 40(6), 1537-1562.

Riggio, R. (2018). Endüstri ve örgüt psikolojisine giriş (B. Özkara, Çev.). Ankara: Nobel.

Rousseau, J. J. (2017). Toplum sözleşmesi. İstanbul: İş bankası Yayınları.

Rowold, J. ve Schlotz, W. (2009). Transformational and transactional leadership and followers' chronic stress. Leadership Review, 9(2), 35-48.

Taş, A., Çelik, K. ve Tomul, E. (2007). Yenilenen ilköğretim programının uygulandığı ilköğretim okullarındaki yöneticilerin liderlik tarzları. Pamukkale Üniversitesi Ĕ̆itim Fakültesi Dergisi, 2(22), 85-98.

Taşkıran, E. (2010). Liderlik tarzının örgütsel sessizlik üzerindeki etkisinde örgütsel adaletin rolü ve bir araştırma (Yayımlanmamış doktora tezi). Marmara Üniversitesi, İstanbul.

Tengilimoğlu, D. (2005). Kamu ve özel sektör örgütlerinde liderlik davranışı özelliklerinin belirlenmesine yönelik bir alan çalışması. Elektronik Sosyal Bilimler Dergisi, 4(14), 1-16.

Terzi, A. R. ve Kurt, T. (2005). İlköğretim okulu müdürlerinin yöneticilik davranışlarının öğretmenlerin örgütsel bağlılığına etkisi. Milli Eğitim Dergisi, 33(166), 98-111.

Turunç, Ö. ve Alkan, Z. (2020). Liderlik tarzlarının örgütsel sessizliğe etkisinde kariyer memnuniyetinin rolü: Eğitim sektöründe bir çalışma. Türk Sosyal Bilimler Araştırmaları Dergisi, 5(2), 90-107.

Uçar, Z. (2016). İşgören sessizliği: Teorik yaklaşımlar temelinde betimsel bir analiz. Beu Akademik İzdüşüm, $1(1), 67-86$.

Yaman E. ve Ruçlar K. (2014). Örgüt kültürünün yordayıcısı olarak üniversitelerde örgütsel sessizlik. Yükseköğretim ve Bilim Dergisi, 4(1), 36-50. 


\section{EXTENDED ABSTRACT}

\section{Introduction}

Google, which is among the most well-known search engines today, lists nearly five hundred million websites related to leadership (Mcshane \& Von Glinow, 2016). While some individuals are on the side of emancipation, others favor the consistency of public order (Rousseau, 2017). Therefore, since there are different management styles, it can be said that those who lead these management styles also have different leadership types. From this point of view, leadership types are also predicted to have different effects on employees in an organization. The same situation can also be observed in education organizations, where different perspectives of management understandings yield to different management types. These leadership types have been examined with various variables. Nevertheless, recent researches in the field demonstrate that the relationship between leadership types and organizational silence is a major field of study. Organizational silence can be explained through the self-monitoring theory which is put forward by Synder in 1974. According to this theory, the individuals tries to socialize by adapting themselves to the society, and this effort determines their specific behaviors in society.

Organizational silence was defined as which employees intentionally hide their knowledge and opinions that has the potential to improve their jobs and institutions (Morrison \& Milliken, 2000). It can be examined under three titles that are acquiescent, defensive, and prosocial silence (Aktaş \& Şimşek, 2014; Taşkıran, 2010). The acquiescent silence is the unquestioned acceptance of the developments in the organization by the employees (Taşkıran, 2010). Defensive silence means that the employee does not express her or his thoughts and opinions with a fear of facing with a tough situation (Çakıcı, 2010; Gül \& Özcan, 2011). Prosocial silence is the employee's concealment of what is known about the job by making sacrifices with the intention of providing benefits for the individuals, organization, and society. The aim here is to protect the benefits of the organization (Gül \& Özcan, 2011). Therefore, it can be claimed that organizational silence will be related to leadership types. Besides, as mentioned above, the scope of the leadership approaches is a very broad field of study; hence, the focus of this study is narrowed into transformational, transactional, and laissez-faire leadership types specifically.

\section{Method}

In this study, a correlational research design was used. The population of the study is teachers working in public high and secondary schools in Istanbul. The sample was determined through the convenient sampling method because of the COVID-19 outbreak, and 401 teachers were reached. School Principals Leadership Style Scale and Organizational Silence Scales for Teachers were used to collect data.

\section{Results}

Results of the study show that organizational silence is negatively related with transformational leadership $(r=-0.374 ; p<0.01)$, while it is positively related with laissez-faire and transactional leadership styles $(r=0.236, p<0.01 ; r=0.238 ; p<0.01$ respectively). Looking at the dimensions of the organizational silence; transformational leadership has negative and low correlations with the dimensions of isolation $(r=-0.262 ; p<0.01)$, administrator $(r=-0.252 ; p<0.01)$, source of the silence $(r=-0.275 ; p<0.01)$; negative and moderate correlations with emotion $(\mathrm{r}=-0.301 ; p<0.01)$ and school environment $(r=-0.499 ; p<0.01)$. Laissezfaire leadership has positive and low correlations with isolation $(r=0.155 ; p<0.01)$, source of silence $(r=0.229 ; p<0.01)$, and emotion $(r=0.161 ; p<0.01)$, and positive and moderate correlation with school environment $(r=0.491 ; p<0.01)$. Lastly, transactional leadership has positive and low correlation with isolation $(r=0.178 ; p<0.01)$, source of silence $(r=0.218 ; p<0.01)$, and emotion $(r=0.176 ; p<0.01)$, while has a moderate positive relationship with school environment $(r=0.416 ; p<0.01)$. So, the first hypothesis is fully supported.

Besides, it is also found out that transformational, laissez-faire, and transactional leadership types explain $16 \%$ of the variance in organizational silence. According to the results of the regression analysis, only transformational and transactional leadership styles were a significant predictor of organizational silence 
( $\beta=-0.35, p<0.01 ; \beta=0.19, p<0.05$, respectively). Therefore, the second hypothesis was partially supported since the hypothesis of $\mathrm{H}_{2} \mathrm{~b}$ which claims the predictor role of the laissez-faire type in organizational silence, was rejected.

\section{Conclusion}

In the study, a significant relationship was found between leadership types and organizational silence. If a school principal has transformational leadership characteristics, organizational silence of teachers decreases. If the principal has laissez-faire or transactional leadership characteristics, organizational silence among teachers increases.

Hiding their thoughts and ideas intentionally, remaining silent in an organization, not only demotivate and lower the performance of the employees, but also create negative consequences for the organization. It will make the administrators blind to chances to detect the problems or probable problems, to intervene and to be cautious for problematic issues right in time and to make the organization improved and progressed. Therefore, preventing the silent atmosphere among the employees can be easily succeeded with an appropriate leadership style. As the results of the study-which is compatible with previous researches in other kinds of organizations- clearly revealed that the transformational leaders who are capable of finding the potential of their employees, of motivating, encouraging and supporting them, will be the best way of management to hear the voices of the employees rather to drag them in a silence all. Especially school environments that are the most important organizations which have the capacity to reform and improve the whole society, are the places to encourage the transformational leadership. Teachers' thoughts and opinions are of crucially important to improve the education environment, and the school administrators should especially listen to them, hear them, and understand their perspectives for a healthier education.

Therefore, school administrators should be invited to participate in seminars and on-the-job trainings to increase their awareness of organizational silence and its probable consequences which may affect the whole school system in a negative way. These seminars should include the appropriate leadership styles, and collaborative and supporting management approaches to prevent silence among teachers, but to encourage them to speak out. 